frequency has been added to its radiometer for more accurate measurements of atmospheric water content, a key factor in the satellite's subsidiary role of weather forecasting. The satellite also carries indigenously developed solar power cells for space qualification tests.

The next step after Bhaskara II will be the 600-kilogramme Indian Remote Sensing Satellite I (IRS I). A memorandum of understanding has been signed with the Soviet Union for launching it in 1986.

But India now has to face the prospect of a much more expensive space programme than in the past, since Bhaskara II marks the end of free launch vehicle and rocket booster facilities provided by the Soviet Union since the launch of the first Indian satellite in 1975.

Indian scientists are working on indigenous launch vehicles as alternatives, although experiments with the SLV-3 launch vehicle have so far achieved only qualified success. Nothing daunted, the Indian Space Research Organization is developing the Augmented Satellite Launch Vehicle (ASLV), based on SLV-3, which can put a 150 -kilogramme satellites into space. India also plans to develop a polar satellite launch vehicle by $1986-87$ to launch 600 -kilogramme satellites into subsynchronous polar orbit 500 to 100 kilometres from the Earth. Sunil Saraf

\section{European environment} \section{One log-jam ends}

\section{Brussels}

The Council of EEC Environmental Ministers which met in Brussels on 3 December was remarkably successful, with agreement being reached on several previously contentious issues.

The directive regulating discharges into the aquatic environment of mercury from the chlor-alkali industry was adopted. Attempts to push through the mercury directive and the "drins" directive (regulating aldrin, dieldrin and endrins) foundered on the dispute over whether quality objectives (favoured by the British) or limit values (preferred on the continent) should be used to assess the maximum permitted level of pollution discharged into water from an industrial plant. The ministers have now agreed on a clause requiring the latest technology to be used when building new plants.

The haggling over the Seveso directive on the prevention of major industrial accidents also ended at the meeting. The new French government has toned down its objections to the clause on the consultation of countries across the frontier from new plants. The consultations will now take place on a bilateral basis - without the involvement of the European Commission as originally proposed. Although the directive does not cover nuclear installations, the same consultation procedure is at the centre of a dispute between France and

\section{Electronic intrigue}

\section{Palo Alto}

In probably the largest theft of semiconductor devices ever, $\$ 2.7$ million worth of integrated circuits disappeared over Thanksgiving weekend from Monolithic Memories Inc., a "Silicon Valley" company.

About 498,000 chips of two types were stolen. One kind, a programmable array, PAL, embodies circuits that provide a logic function in a wide range of computer products including video games, industrial equipment and computers used by the military. The second type, FIFO, is used to input data at one speed into computers and take it out at another.

About $\$ 20$ million worth of advanced computer chips disappear each year into a national and international underworld electronics trade. Integrated circuits are smaller than a fingernail, hard to identify and can sell for $\$ 100$ apiece. Many stolen chips are smuggled out of the United States into Eastern Europe. President Reagan's embargo on allowing Communist countries to buy high technology equipment provides a good market. Other chips are sold to pay narcotics dealers.

In 1979, an employee at INTEL stole 10,000 microcomputer devices worth $\$ 1$ million. They passed through blackmarket distributors in West Germany and eventually arrived at Siemens, a West German computer manufacturer. This robbery was traced when Siemens told INTEL that the untested chips were faulty. That the intensive electronic and human security at Monolithic Memories was bypassed suggests that in this case also the thief was an employee: the company is offering a reward of $\$ 50,000$ for information leading to an arrest.

Charlotte K. Beyers

Belgium. The French government intends to build power stations at Chooz, a few kilometres from the Belgian border.

Agreement was reached on a technical proposal to exchange data on sampling and monitoring levels of atmospheric pollution. However, the directive on safety levels for lead in air must wait until a communally acceptable method of monitoring atmospheric pollution is found.

Broad agreement was reached on the European Commission's third environmental action programme and its proposed policy to give environmental considerations greater weight when determining other EEC policies. Finally, despite much discussion, there was no decision to implement the Washington Convention the EEC regulation on the trade in endangered species is, in fact, reported to be much tougher than the convention.

Jasper Becker
Animal welfare Promise delayed

The new European legislation to protect laboratory animals seems to be in the hands of legislative snails. Optimists had expected agreement on the draft of a Council of Europe convention on "the protection of animals used for experimental purposes" last May. But the deadline passed, and the hope now is for agreement in March 1982.

Discussions have been under way since 1978, when the Council of Europe appointed an expert committee to draft model legislation. But the experts have so far failed to agree among themselves. Their latest disagreements relate to the "pain condition" that if an animal suffers severe and enduring pain, the experiment must stop and the animal be killed; the use of animals for more than one experiment; and the experimental procedures which should be included in the statistics on animal experiments.

Most of the representatives from the council's 21 member states object to the lack of provision for exemption from the pain condition in the latest draft. The exception is Britain, which wrote the draft when it took over chairmanship of the committee in April 1980. Britain argues that its own legislation, which includes the pain condition without exemption, has worked well since it was enacted in 1929.

Approval of the convention is also being held up by West Germany's objection to a clause which permits an animal used in one painful experiment to be used again. Most other countries accept the clause, some less willingly than others. A further stumbling block relates to whether animals used as controls, for example, should be included in statistics on animal experiments. Sweden believes that they should, but most other countries think their inclusion would push up the apparent number of experiments unncessarily.

The aim is to resolve these differences before the next annual meeting of the expert committee in March. When agreement is reached, however, a council of ministers will have to approve the draft before it can be laid before individual states for signature and ratification. Because ratification is a lengthy process, the convention is unlikely to come into force for several years.

Meanwhile, the European animal welfare lobby, increasingly vociferous, is asking for tighter controls than those in the latest draft. The Council of Europe's parliamentary assembly, which has no power but which can be influential, has agreed to discuss the lobby's demands and consider recommending changes to the terms of reference of the expert committee. If the assembly decides to recommend changes and the council of ministers agrees to implement them, the convention could be delayed indefinitely or even killed.

That, however, is unlikely. Most states 
are eager for a convention as soon as possible, if only to head off the animal lobby's more extreme demands. Some, such as the United Kingdom, have already delayed national legislation pending a convention. Britain's Conservative government now has little more than two years in which to fulfill its last election promise to update the Cruelty to Animals Act of 1876 . Two recent private members' bills to do just that have already come to grief. Judy Redfearn

\section{French reorganization}

\section{Sector structure}

\section{Grenoble}

Jean-Pierre Chevènement, Minister for Science and Technology in France, has finally decided on the structure and organization of his ministry. He has reaccumulated all the instruments and organizations of science and technology policy — dispersed since de Gaulle last had a major science ministry - and sorted them into a new structure.

The Delegation-Générale à la Recherche Scientifique et Technique, which acted as the relatively small office of the previous science minister, is to be disbanded and its staff re-absorbed. The same fate awaits the Délégation à l'Innovation et à la Technologie (which previously worked within the Ministry of Industry).

The new structure is claimed to be something midway between the highly dispersed "Rothschild" system of the United Kingdom in which individual ministries have control of large sums of research money which they can spend with research councils broadly as they wish, and the highly centralized German system; but the Chevènement structure is on the face of it considerably closer to the German than the British model.

The ministry will be divided into three sectors (plus the cabinet of personal advisers, which will be extended with the addition of a section to evaluate the progrees of his policies). There will be a "Direction de la Politique Générale", which, broadly speaking, will administer basic science through the "grands organisms" (the Centre National de la Recherche etc); a "Direction du Développement Scientifique et Technique et de I'Innovation' which will actively promote contacts between science and industry and mastermind the scientific renovation of the French economy (the matter closest to Chevènement's heart); and a high-flying "Mission Scientifique et Technique". This body, headed by Yves Farges, a one-time solid-state physicist and the principal advocate for a European synchrotron radiation source, will act as a kind of interface between the other two sectors and the minister himself.

The staff of the ministry at present numbers some 250 . By the time the changes are complete - and the ministry has moved to a new location on the Montagne Ste-
Geneviève (the old site of the Ecole Polytechnique) the staff will probably have grown to 400.

Robert Walgate

\section{Scientific fraud}

\section{In Bristol now}

A further case of falsification in the scientific literature has come to light. The following letter has been received from $\mathrm{Dr}$ M. J. Purves of the Department of Physiology at the University of Bristol:

SIR - I very much regret to have to report that data published in the preceedings of the 28th International Congress of

Physiological Sciences (Purves, M.J. 1981 Cerebral Blood Flow and Metabolism in the Sheep Fetus. Advances in Physiological Sciences 9: 199; 126. Pergamon, Oxford \& Adademiai Kiado, Budapest) are false. I must also emphasize that none of my colleagues was involved in the preparation of this paper and the responsibility was mine alone.
Bristol, UK
M.J. Purves

Dr Purves, a reader at the University of Bristol, resigned his post with effect from 1 November after an internal investigation.

The paper concerned describes the use of recently developed techniques for investigating the function of the mammalian (sheep) brain in utero. The article describes the use of 5-deoxyglucose as an index of metabolic activity in central nervous metabolism. One of the objectives of the study was to demonstrate that 5 -deoxyglucose (not metabolized in the usual way) is taken up more slowly by the fetal mammalian brain during periods when the embryo is asleep.

The University of Bristol seems to have acted quickly since some of Dr Purves's junior colleagues drew attention to the irreproducible features of his published paper earlier in the year. An agreed announcement of the circumstances was delayed for family reasons. Dr Purves said earlier this week that the falsifications consist of the data published. His senior colleagues say that they cannot understand why such a talented person, well-supported by the Wellcome Foundation and the Public Health Services, should have followed such a course.

\section{Erratum}

Nature must apologise to one or other (or both) of Sir Andrew Huxley (President of the Royal Society) and Professor T.R.E. Southwood that the latter's photograph appeared last week in place of the former's. The Royal Society's anniversary celebrations this year appear to have been especially prone to accident - the President of the Fellowship of Engineering, half-way through an impassioned speech on the importance of engineering, referred to the present President's predecessor-but-one, Dr $f$..L. Hodgkin, as Professor Hodgkinson.
Primitive life in France

Paris

The life and times of Europe's earliest inhabitants form the focus of a new exhibition at the Musée de l'Homme in Paris. The exhibition, which opened on 9 December and will run until April 1983, illustrates major advances in human development over more than a million years of European prehistory.

Evidence of human presence beginning with what are reputed to be the oldest stone tools in Europe is traced up to the appearance of fully evolved Neanderthals some 125,000 years ago, Remains from more than 100 sites in 13 European countries are on view, combined with replica living floors and two reconstructions of palaeolithic shelters.

The main advance portrayed in the exhibition, according to Professor Henry de Lumley, exhibition organizer and director of the Laboratory of Prehistory and the museum, is the domestication of fire in Europe some 400,000 years ago. By 300,000 years ago distinct cultures throughout Europe possessed knowledge of fire, were making various tool assemblages, living in organized encampments and hunting in groups.

By this time too, early Europeans had apparently begun to construct more elaborate living shelters with several distinct areas. The remains of two such living floors from sites excavated by Professor de Lumley provide the basis for the striking hypothetical recreations of a hut from Terra Amata and a cave shelter at Le Lazeret (both near Nice in France).

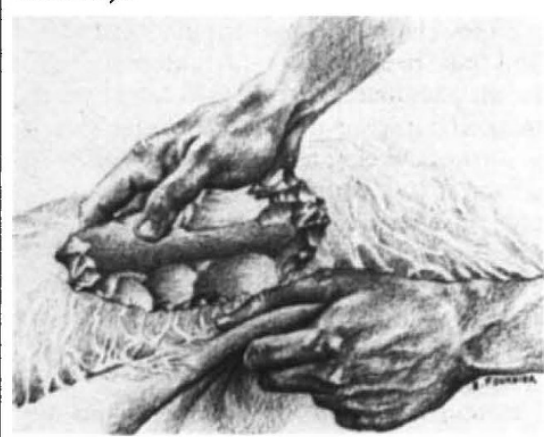

The Terra Amata hut is built from wood poles and pine branches on a replica rocky Mediterranean shore and is based on remains dated at about 380,000 years ago. The Le Lazaret cave shelter suggests an even more comfortable lifestyle by about 130,000 years ago.

Specialists may well debate the interpretation of the stones, bones, dates and reconstructions in this exhibition, but all visitors will go away with a lasting impression of how prehistorians recreate the past and what daily life might have been like for Europe's earliest inhabitants.

Richard Dreiman 